\title{
ФУНКЩИЯ АДМИНИСТРАТИВНЫХ СУДОВ В ЗАЩИТЕ ПРАВ И СВОБОД
}

\author{
МАМЕДОВА Кенуль Рафиг гызы - член Коллегии адвокатов \\ Азербайджанской Республики,адвокат, старший научный сотрудник и диссертант \\ Института Права и Прав человека НАНА
}

DOI 10.32782/LAW.UA.2021.4.6

\begin{abstract}
В статье исследуется место административных судов Азербайджанской Республики в судебной системе странъ. Принимается во внимание, что хотя в сбере защить прав и свобод человека, а также нарушенных интересов действуют различнье учреждения и структуръи, но они не так эбббективнъ, как cydzr.

В то же время системно изучается законнъий надзор за деятельностью административного органа посредством административного производства, а также исключительная роль суда в восстановлении нарушенных прав. Утверждается, что судебнъий надзор за деятельностью административных органов воплощается в восстановлении нарушенных прав и интересов граждан.

Ключевъе слова: судебная система, закон, административное производство, надзор, процедурнъий порядок, права и свободъ, правосудие
\end{abstract}

В круг полномочий судов, осуществляющих правосудие, входит как регулирование споров разного рода, так и разрешение по существу споров между людьми, государственными и негосударственными органами, и установление наиболее оптимального законного решения. Неоспоримый факт, что правосудие играет неоценимую роль в системной организации механизма государственного управления соответствующего законопорядку, в обеспечении стабильности, общественного порядка, следованию зако- ну, формировании правосознания, культуры.

Именно это является причиной указания того, что суды осуществляют одну из основных функций государства по поддержанию дисциплины, порядка и мира в обществе, обеспечению законности, стабильного разрешения споров (1, с.8).

Присмотревшись к опыту каждой развитой страны, которая ставит приоритетом построение демократического, правового, светского государства и рассматривает защиту прав и свобод человека как ключевой фактор построения сильного государства, при этом руководствуясь повышением благосостояния народа, как основного источника власти, возможно убедиться в том, что суды считаются отдельной ветвью власти обладающей важным значением.

По мнению некоторых ученых, правовое государство отражает не только формальную законность, которая обеспечивает периодичность и последовательность в установлении и поддержании демократического порядка, но и справедливость, основанную на признании и уважении прав и свобод человека $(2$, с.40).

Следует принять во внимание, что хотя в сфере защиты прав и свобод человека, а также нарушенных интересов действуют различные учреждения и структуры, но они не так эффективны, как суды.

По этой причине в юридической литературе делается вывод о том, что хотя суд и не является лучшим средством разрешения 
конфликтов, но, к сожалению, человечество еще не знает более совершенного механизма для этого (3).

После обретения независимости, Азербайджанская Республика провела экономические, социальные, политические и правовые реформы, в которых постоянно придавалось особое значение человеку, его правам и свободам, здоровью и личной жизни. Конституция Азербайджанской Республики, принятая 12 ноября 1995 года, провозглашая высшей целью государства защиту прав и свобод человека и гражданина, и обеспечение достойного уровня жизни граждан Азербайджанской Республики, определила вектор проведения правовых реформ различной направленности для неуклонного соблюдения законности и правопорядка всеми без исключения.

Государственная власть в Азербайджанской Республике организована на основе принципа разделения властей. Хотя каждой ветвью власти в демократических государствах осуществляется определенная функция, но в отличие от других ветвей власти, роль и миссия судебной власти, заключается в обеспечении верховенства права по различным правовым спорам, как это и предусмотрено в Конституции, законах, подзаконных актах, а также международных договорах. Из этого делается вывод, что судебная власть обеспечивает защиту прав, справедливости, равноправия в обществе, а также граждан, от противоправных посягательств и произвола.

Одна из основных целей судебной реформы в стране, проводимой Указом от 1 декабря 1998 года о применении Закона «О судах и судьях», принятого для регулирования деятельности судов в Азербайджанской Республике - обеспечение верховенства законов в целях установления справедливости, наличие особого места судебной власти в правосудии, принятие и защита прав и свобод человека как высшей ценности и создание для этого грамотного, профессионального корпуса судей и др. (4).

Исторический обзор показывает: хотя и есть в определенном смысле некоторые различия между традиционным административным правом и современным адми- нистративным правом, в литературе можно рассмотреть, что правовое государство тесно связано с административным правом и что они взаимоохватывают друг друга.

Как уже выше упоминалось, Закон «Об административном производстве» был принят 21 октября 2005 года в Азербайджанской Республике для обеспечения административными органами реализации прав и свобод человека, разрешения конфликтов между административными органами и гражданами на правовом уровне и обеспечения соблюдения законов. Поскольку действующий Закон был принят для разрешения споров особых категорий, для обеспечения исполнения этого закона необходимо было создать специализированный суд в этой сфере. Как результат этого, Указом Президента Азербайджанской Республики от 15 июля 2010 года были образованы новые суды с целью совершенствования судебной системы в нашей стране. Одной из созданных новых судебных систем стали организованные на основе Местных Әкономических судов Административно-Әкономические суды (ныне Административные суды и Коммерческие суды).

Уже повторно, в связи с возникшей необходимостью, в судебной системе были проведены новые реформы и Распоряжением Президента Азербайджанской Республики от 19 июля 2019 года по применению Закона Азербайджанской Республики от 9 июля 2019 года за № 1632-VQD «О внесении изменений в Закон Азербайджанской Республики «О судах и судьях», в нашей стране вместо Административно-Экономических судов был создан ряд новых отдельных Административных судов и Коммерческих судов. Действующее Распоряжение оказало положительное влияние на дальнейшую специализацию судей в сфере их юрисдикции, на особое внимание в подходах к судебным разбирательствам, находящимся в их производстве и другим подобным случаям. Регулирующий для административных судов процедурный порядок административного судопроизводства - Административно-Процессуальный Кодекс Азербайджанской Республики, был принят Законом Азербайджанской Республики от 30 июня 2009 года 


\section{Теорія, історія держави і права, конституційне право}

«Об утверждении Административно-Процессуального Кодекса Азербайджанской Республики».

Взяв за основу осуществление деятельности административного судопроизводства, оно может оцениваться как своего рода надзор за деятельностью некоторых административных органов, а также как деятельность органа, препятствующего нарушению административными органами гражданских прав. К надзорной функции административного суда в юридической литературе существуют различные подходы ученых. По мнению Н.Г. Салишевой, административная юстиция - это система внешнего контроля за действиями административных органов и их должностных лиц по отношению к гражданам $(5$, с.78).

В настоящее время в Азербайджанской Республике в порядке административного судопроизводства рассматриваются различные иски, куда можно отнести: иски по оспариванию (отмене или изменению) административного акта, принятого административным органом в связи с правами и обязанностями лица (иск об оспаривании); исковые требования о возложении на административный орган соответствующего обязательства в связи с принятием административного акта либо иска о защите от бездействия административного органа (иск о принудительном исполнении ); иски о совершении административным органом определенных действий, не связанных с принятием административного акта (иск об исполнении обязательства); и др. (6, с.18).

В случае необходимости по вышеуказанным искам, при соблюдении процедурных правил возможно обратиться в суд по подведомственности, и тогда спор может найти разрешение в порядке административного судопроизводства. Судебный надзор за законностью деятельности административных органов обеспечивает возможность гражданскому обществу быть услышанным, не соглашаться с действиями, не отвечающими его интересам, и оспаривать административные акты (административная юстиция) (7).

Специфический признак, характеризирующий данный вид надзора, выражается в проверке органами правосудия законности действий органов власти (8, с.269).

Принимаемые административными органами определенные административные акты являются одними из подразумеваемых обстоятельств, могущих стать причиной нарушения прав. Во избежание таких случаев, в административном судопроизводстве предусмотрено приостановление исполнения принятого административного акта до окончания рассмотрения спора в суде и принятия заключительного акта, принятия мер защиты временного характера, а также наложения на административный орган штрафа в установленном законодательством порядке. Тот факт, что административный суд находит законное решение спора, предоставленные ему полномочия по восстановлению справедливости и сами вышеперечисленные нюансы, указывают на наличие судебного надзора за деятельностью административных органов. Судебный надзор за деятельностью административных органов воплощается в восстановлении нарушенных прав и интересов граждан. Такие характеристики, как превосходящие полномочия административных органов, их публичная сила, а иногда и их способность действовать в ограниченных масштабах, по сравнению с субъектами частного права, являются важными основаниями для выделения административного судопроизводства в качестве независимого вида судебного производства $(9$, с.20).

Административный суд, в период нахождения дела в судебном производстве, создает условия для выполнения административным органом своих обязанностей, принятия необходимого административного акта либо обеспечения его изменения, отмены до окончания судебного разбирательства. Әта функция создает благодатную почву для разрешения дела в короткие сроки, устранения коллизий, противоречий, возможность экономии времени, предотвращения волокиты и принятия законных мер против административного органа, допустившего ошибку.

В качестве заключения можно утверждать, что административный суд, будучи государственным органом, выполняющим 
посредством судебного производства своего рода миссию судебного надзора над административными органами, является специальным институтом, который создает условия для обеспечения конституционных прав и свобод граждан, обеспечения адекватных требований закона в отсутствии дискриминации и устанавливающим ответственность в случаях, установленных законодательством.

\section{Литература}

1. Principles for Judicial Administration: Governance, Case Administration, Essential Functions and Funding. Draft Report. National Centerfor State Courts - V3 DRAFT 7-15-2010

2. Абуллаев А., Азаров А., Хюфнер К., Рейтер В. Права человека. Международные и национальные механизмы защиты. Баку, 2008 (на азербайджанском языке)

3. Абдраимов Б.Ж. Административная юстиция: Соотношение моделей и выбор цели. Юрист, 2003, № 12

4. Указ Президента Азербайджанской Республики от 1 декабря 1998 года о применении Закона «О судах и судьях» (на азербайджанском языке)

5. Салищева Н.Г. О некоторых споcoбах защиты и охраны прав, свобод и законных интересов граждан в сфере деятельности исполнительной власти в Российской Федерации // Конституция Российской Федерации и совершенствование механизмов защиты прав человека. М., 1994

6. Джафаров И.М. Административное производство (научно-теоретический комментарий). Баку: Конфедерация Юристов Азербайджана, 2011 (на азербайджанском языке)
7. Административно-процессуальный Кодекс Азербайджанской Республики. Баку. Издательство Дигеста. 2019 г. (на азербайджанском языке)

8. Кассезе С. Развитие административного государства в Европе // ДПП ИМП 2 (2012)

9. Гусейнова Н.Ш. Сущность и правовая природа административного производства / Материалы научно-практической конференции «Актуальные проблемы юридической науки в глобализирующемся обществе». Баку, 2009 (на азербайджанском языке)

\section{Mammadova Konul Rafig FUNCTION OF ADMINISTRATIVE COURTS IN THE PROTECTION OF RIGHTS AND FREEDOMS}

The article examines the place of the administrative courts of the Republic of Azerbaijan in the judicial system of the country. It is taken into account that, although various institutions and structures operate in the field of protecting human rights and freedoms, as well as violated interests, they are not as effective as the courts.

At the same time, the legal supervision of the activities of the administrative body through administrative proceedings, as well as the exclusive role of the court in the restoration of violated rights, are systematically studied. It is argued that judicial supervision over the activities of administrative bodies is embodied in the restoration of violated rights and interests of citizens.

Keywords: judicial system, law, administrative proceedings, supervision, procedural order, rights and freedoms, justice 